\title{
ArcheoSciences
}

Revue d'archéométrie

33 (suppl.) | 2009

Mémoire du sol, espace des hommes

\section{An area of the gallic oppidum of Gondole (Le Cendre, Puy-de-Dôme, France) revealed by magnetic survey: extrapolation from excavation data}

Yann Deberge and Michel Dabas

\section{CpenEdition}

\section{Journals}

Electronic version

URL: https://journals.openedition.org/archeosciences/1717

DOI: 10.4000/archeosciences. 1717

ISBN: 978-2-7535-1599-4

ISSN: $2104-3728$

\section{Publisher}

Presses universitaires de Rennes

\section{Printed version}

Date of publication: 30 October 2009

Number of pages: $287-290$

ISBN: 978-2-7535-0943-6

ISSN: $1960-1360$

\section{Electronic reference}

Yann Deberge and Michel Dabas, "An area of the gallic oppidum of Gondole (Le Cendre, Puy-de-Dôme, France) revealed by magnetic survey: extrapolation from excavation data", ArcheoSciences [Online], 33 (suppl.) | 2009, Online since 30 October 2011, connection on 21 September 2021. URL: http:// journals.openedition.org/archeosciences/1717 ; DOI: https://doi.org/10.4000/archeosciences. 1717 


\title{
An area of the gallic oppidum of Gondole (Le Cendre, Puy-de-Dôme, France) revealed by magnetic survey: extrapolation from excavation data
}

\author{
Yann Deberge* and Michel Dabas **
}

Key words: Magnetic survey, Aerial survey, Oppidum, Craftworking features, Cut features (pits, cellars, ditches).

The Gallic oppidum of Gondole (Le Cendre, France) has been subject to a variety of archaeological surveys since the year 2000. Mechanical trenching and aerial photography show that the site occupies an area of 70 hectares. The proto-urban layout of the site has been revealed in a limited excavation $\left(3500 \mathrm{~m}^{2}\right)$ and some of the better quality aerial photographs. As part of the ANR Celtecophys project a magnetic survey was conducted by GEOCARTA. The survey covered an area of 3.5 hectares and included the area previously excavated.

Despite the unfavourable geological context (alluvial deposits with basaltic pebbles) several anomalies that could be interpreted as archaeological features were identified. The comparison between the magnetic survey (Fig. 1) of the previously excavated features and the adjacent area enabled the interpretation of magnetic anomalies.

Based on information gathered on the excavated area we noted that:

- cellars are easily identifiable with a distinctive signal difference depending on the depth of the features : the shallower constructions give off a weak signal and show up on the plan as uniform grey patches that are quite difficult to pick out ; the deeper cellars give off a much stronger signal with a strong bipolarisation;

- the pottery kilns, theoretically very magnetic, show up as strong isolated anomalies. The surface survey and the excavation results for these features are perfectly correlated and even show the internal organisation of each kiln with the furnaces towards the west and the associated pits towards the east. The bronze-working pit shows up as a white strip (negative);

- the more isolated features, pits, wells.etc. are more or less visible on the magnetic survey and are generally represented by less noise.

The magnetic map records most of the previously excavated features (Fig. 2). The cellars, palisade trenches and kilns are easily identifiable and their position corresponds to that given in the plan of the excavation. The pits and wells are not as easily identifiable and the stone trackway is not perceptible in the surface survey.

Some of the linear anomalies that have appeared on the magnetic survey are not archaeological features and could well be modern plough marks.

* INRAP Clermont-Ferrand/UMR ANR CETECOPHYS/UMR AOROC CNRS/ENS-Paris.

** Directeur scientifique GEOCARTA. 


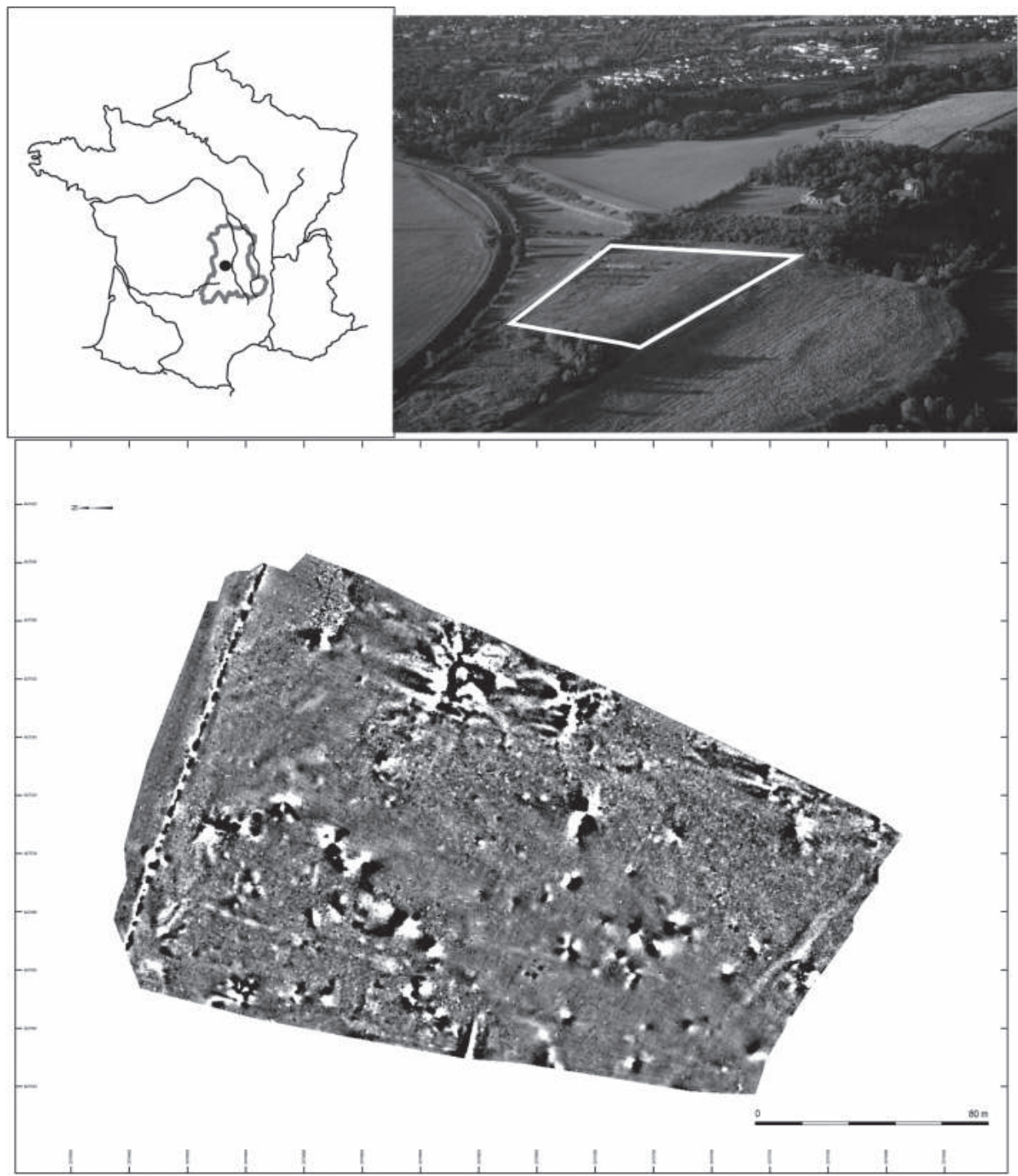

Figure 1: Location of the excavation and of the area subject of the magnetic survey.
Using the 2005-2008 excavation results we have proposed to interpret the results obtained from the magnetic survey of the surrounding area. We insist on the fact that these interpretations remain hypothetical and are based on observations obtained from recently refilled excavated features. We cannot be certain that features refilled 2000 years ago will give off the same magnetic signal.

About 30 magnetic anomalies picked up by the surface survey with strong bipolar signals are very similar to the signals recorded over the previously excavated cellars and 17 other readings seem to match the pottery kilns. Five possible kilns show up just next to a previously excavated well. At the time of excavation this well contained a large amount of finds, almost all of which were badly fired ceramics and elements of burnt lining clay. A further 40 weaker anomalies are likely to be wells and other smaller features.
The results of the aerial survey carried out in 2008 (Fig. 3) are partly identical to the two other surveys. About 20 features are visible in the same places on the plans. It seems more than likely that these two survey methods are complementary. If we add the aerial and magnetic anomalies, we can identify 50 large features that are probably cellars and a further 80 smaller features. The number of probable unexcavated features is roughly the same as the density estimation made based on the excavation results.

To sum up, both surface survey methods are complementary and show an organized layout of archaeological features. The cross-referencing of surface surveys with recently excavated areas has enabled us to interpret signals that normally would have been classed as insignificant. In the near future we plan to check the results obtained from the surface surveys by mechanical excavation. 


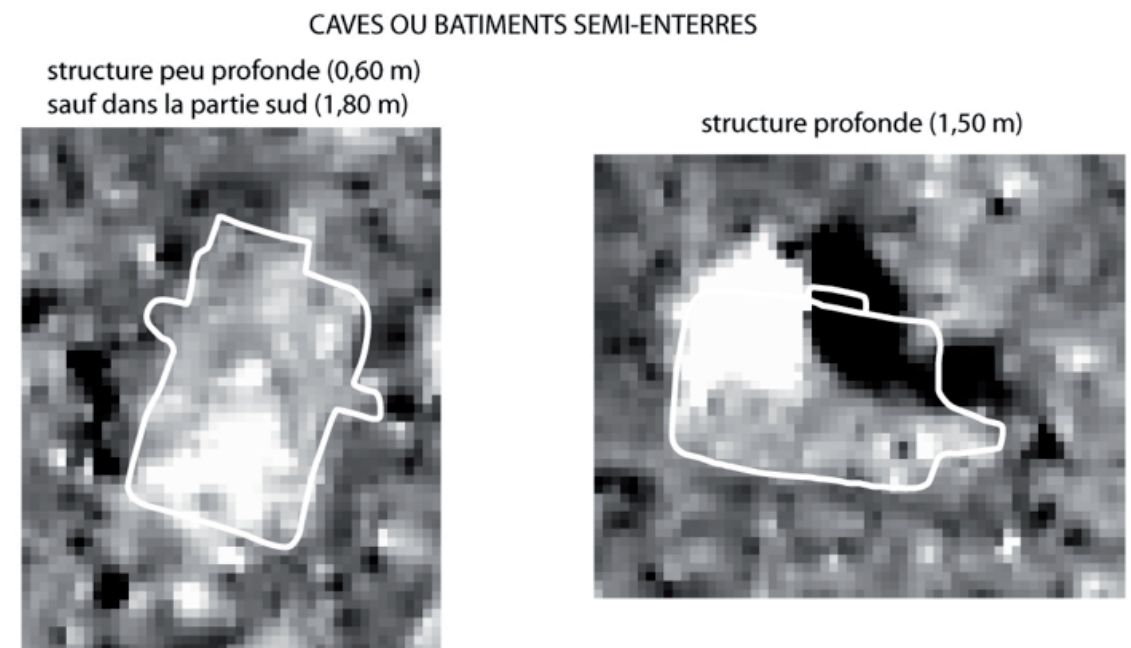

\section{STRUCTURES ARTISANALES}

four à deux laboratoires de cuisson et une fosse atelier

four à trois laboratoires de cuisson et

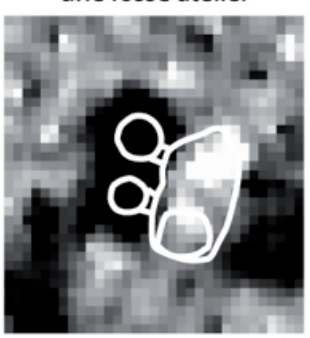
une fosse atelier

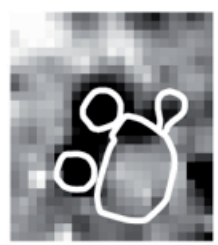

four de bronzier

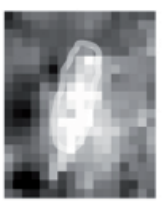

STRUCTURES DIVERSES
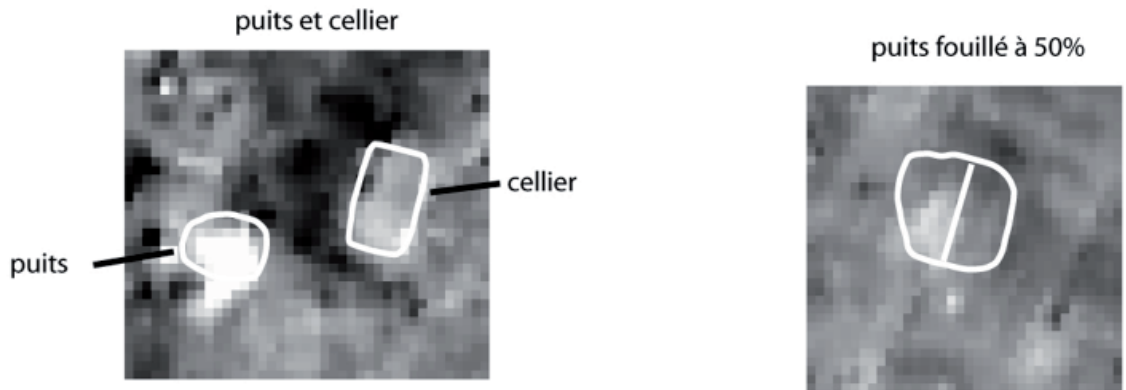

0 $10 \mathrm{~m}$

Figure 2: Magnetic anomaly interpretation based on the previously excavated features. 


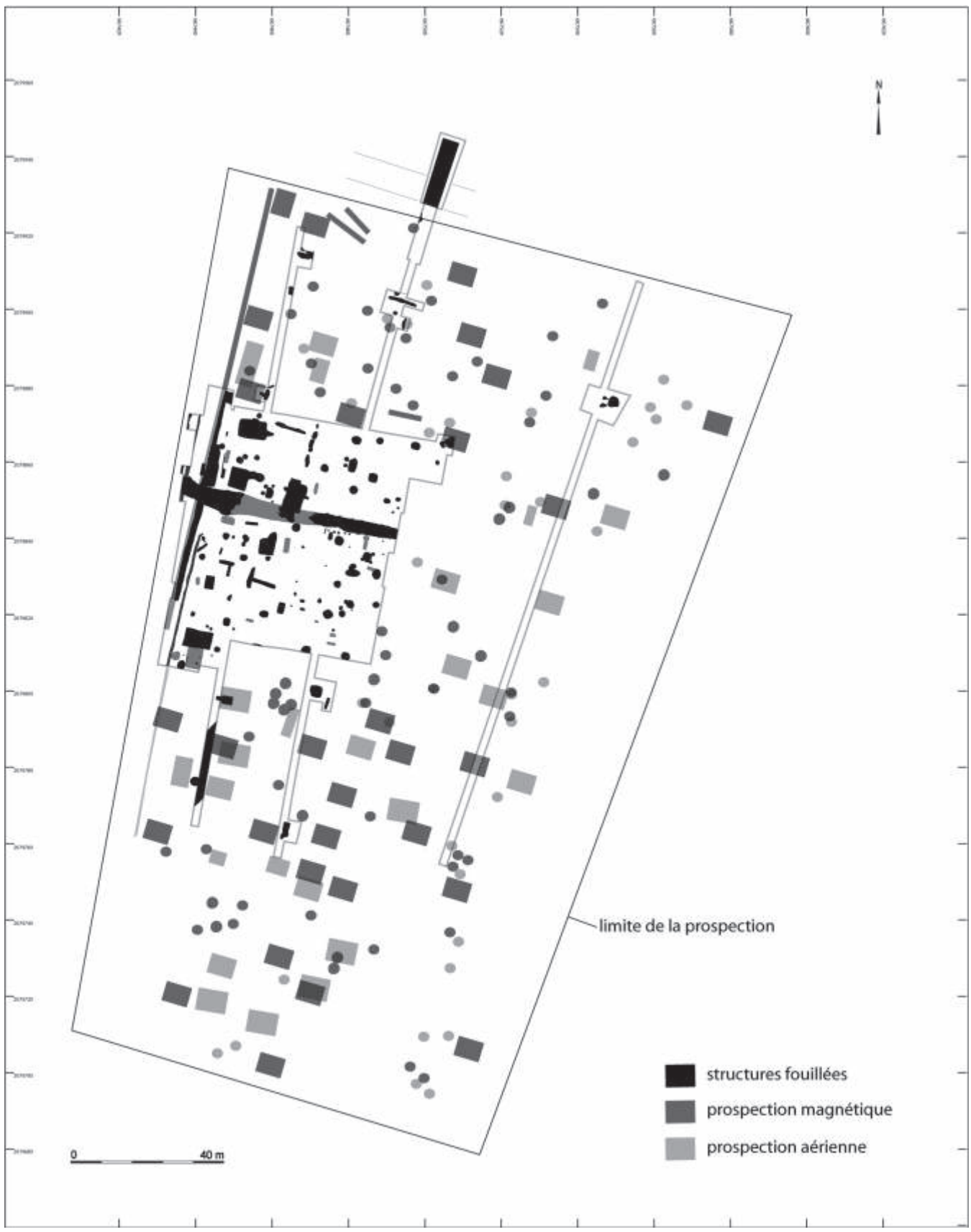

Figure 3: Comparison between magnetic survey results and aerial survey results. 